\title{
Preharvest Bagging as an Alternative Technique for Enhancing Fruit Quality: A Review
}

\author{
Nana Millicent Duduzile Buthelezi ${ }^{1}$, Tieho Paulus Mafeo ${ }^{1}$, \\ and Nhlanhla Mathaba ${ }^{2}$
}

AdDitional INDEX WORDs. antioxidants, bag type, diseases, fruit color, pests

SumMary. Preharvest factors such as poor orchard management and field sanitation can lead to pathological infection of the tree fruit being grown as well as insect pest infestation, resulting in poor postharvest fruit quality. Wind and hail damage may cause significant tree fruit abrasions and blemishes. Consequently, these preharvest factors may reduce yield and cause market and economic losses. One of the most successful methods used to manage tree fruit pathogens and insect infestation is the application of agrochemicals, predominantly fungicides and insecticides. However, this method has recently been criticized due to the adverse effects on field workers' safety, consumers' health, and the environment. The development and use of preharvest bagging are among the most environmentally friendly technologies intended for safe enhancement of tree fruit quality. The technique protects tree fruit against pathogens, insect pests, physiological disorders, agrochemical residues, fruit abrasions, sunburn, and bird damage, and it further modifies the microenvironment for fruit development with its various beneficial effects on its external and internal quality. Furthermore, because of the global restrictions of agrochemicals and social awareness, this technique provides extensive relief to growers and consumers. However, bagging is labor-intensive and expensive; therefore, its benefits or advantages and disadvantages must be thoroughly investigated if it is to be promoted commercially. This review examines the improvement of tree fruit quality by the application of preharvest bagging during early stages of fruit growth and development. The latest advances in the development and use of tree fruit bagging and its economic impact and cost-benefit ratio are discussed, as are recommendations for the formulation of bagging materials that could be valuable in the future.

$\mathrm{T}$ The preharvest and postharvest quality of fruit grown commercially are influenced mainly by preharvesting activities during fruit growth and development, which include orchard management practices (Tyagi et al., 2017). During its development stages, the fruit is prone to invasion by insect pests, bird attacks, various pathogens, and mechanical damage, all of which can reduce its commercial value, thereby causing significant yield and economic

Received for publication 25 May 2020. Accepted for publication 28 Oct. 2020.

Published online 30 December 2020

${ }^{1}$ Department of Plant Production, Soil Science, University of Limpopo, Private Bag X1106, Sovenga, 0727, South Africa

${ }^{2}$ School of Agricultural Sciences, University of Mpumalanga, Private Bag X11283, Mbombela, 1200, South Africa

N.M.D.B. is the corresponding author. E-mail: duduzilebuthelezi@yahoo.com.

This is an open access article distributed under the $\mathrm{CC}$ BY-NC-ND license (https://creativecommons.org/ licenses/by-nc-nd/4.0/).

https://doi.org/10.21273/HORTTECH04658-20 losses (Kasso and Bekele, 2018; Sharma et al., 2009). For example, pathogens, bird attacks, and physiological disorders may manifest through fungal white mold (Sclerotinia sclerotiorum) and bacterial spot (Xanthomonas axonopodis), holes, and surface cracks, resulting in diminished, distorted, or discolored mature fruit (Santosh et al., 2017; Tyagi et al., 2017). Furthermore, harsh environmental conditions, such as excessive sunlight, wind, and hail, can result in peel sunburn or scald and fruit abrasion (Qin et al., 2012; Sharma et al., 2009; Tyagi et al., 2017).

Insect attacks and pathological and physiological disorders have been controlled worldwide by agrochemicals such as fungicides and insecticides since the middle of the last century (De Bon et al., 2014; Masia et al., 2014). These agrochemical treatments can be intensive and require skilled laborers compared with traditional methods such as biological control, weeding, and pruning (Gallardo et al., 2016; Hilje et al., 2001 ), with optimum control provided by applications every 5 to $7 \mathrm{~d}$ during the fruit-growing season (Diepenbrock et al., 2016). However, this practice is costly in terms of materials and labor, and growers are challenged to meet the maximum residue limits and preharvest application intervals while maintaining control of pests. Farnsworth et al. (2017) and Goodhue et al. (2011) reported that the insecticide material and application (labor and equipment) costs for raspberry (Rubus idaeus) and strawberry (Fragaria $\times$ ananassa) are $\approx \$ 825.33$ and $\approx \$ 1161.28$ per hectare, respectively. Furthermore, frequent and regular applications increase the risk of insecticide resistance (Asplen et al., 2015; Wiman et al., 2016) and pose risks to beneficial arthropods, including natural enemies that keep secondary pests below the levels at which they cause damage (Biondi et al., 2012). Residues of these agrochemicals can also be found on food samples, thereby threatening not only human health when eaten but also the environment (Masia et al., 2014; Pareja et al., 2011). Consequently, in the 1970s and 1980s, the European Union (EU) established strict regulations banning many pesticides (Masia et al., 2014). As a result, to reduce the detrimental effects of pest and disease infestation and curtail the use of agrochemicals, bagging was identified as an alternative technique for fruit production that involves enclosing individual fruit or bunches or clusters in bags on the tree for a specific period (Sharma et al., 2014; Zhou et al., 2012).

\begin{tabular}{llll}
\hline $\begin{array}{l}\text { Units } \\
\begin{array}{l}\text { To convert U.S. to SI, } \\
\text { multiply by }\end{array}\end{array}$ & U.S. unit & SI unit & $\begin{array}{l}\text { To convert SI to U.S., } \\
\text { multiply by }\end{array}$ \\
\hline 0.4047 & acre $(\mathrm{s})$ & ha & 2.4711 \\
2.54 & inch $(\mathrm{es})$ & $\mathrm{cm}$ & 0.3937 \\
25.4 & inch $(\mathrm{es})$ & $\mathrm{mm}$ & 0.0394 \\
$\left({ }^{\circ} \mathrm{F}-32\right) \div 1.8$ & ${ }^{\circ} \mathrm{F}$ & ${ }^{\circ} \mathrm{C}$ & $\left({ }^{\circ} \mathrm{C} \times 1.8\right)+32$
\end{tabular}


Preharvest bagging is a phytosanitary practice used by farmers to protect fruit from the attacks of pests, such as fruit fly (Anastrepha sp.), guava weevil (Conotrachelus psidii), and red mite (Monalonium annulipes), and also from rust (Puccinia psidii) (Bilck et al., 2011; Sharma and Sanikommu, 2018). It contributes to the elimination of or reduction in the use of insecticides and fungicides and further protects the fruit from pathological and physiological disorders, bird attacks, sunburn, and mechanical damage such as abrasion, cracking, and russeting (Abbasi et al., 2014; Feng et al., 2014; Liu et al., 2015). Bagging also modifies the microenvironment of the fruit during its development, with multiple effects on its internal quality (Liu et al., 2015; Sharma and Sanikommu, 2018). For example, Sharma et al. (2013) and Zhou et al. (2019) reported that preharvest bagging using spunbonded light yellow fabric, polypropylene, and reflective films significantly improved peel color, firmness, total soluble solids, and ascorbic acid and anthocyanin synthesis in apples (Malus $\times$ domestica) and pears (Pyrus communis) compared with control. Islam et al. (2017) reported that preharvest bagging of mango (Mangifera indica) using brown and white paper, muslin cloth, and wavelengthselective (ultraviolet transparent) plastics effectively enhanced fruit length, weight, diameter, total soluble solids, citric acid, reducing sugar, total sugar, and $\beta$-carotene contents compared with control (Table 3). Bagging can also reduce levels of light-absorptive compounds, which are inherent in some fruits, such as anthocyanin, resulting in the higher sensitivity of bagged fruit to solar irradiation. This helps to achieve uniform product coloration by promoting anthocyanin synthesis when bagged fruit is re-exposed to sunlight (Bilck et al., 2011; Sun et al., 2014; Zhu et al., 2018). Therefore, preharvest bagging has become a selectively necessary technique for improving the commercial value and securing the export market of fruits (Qin et al., 2012).

Preharvest bagging has been practiced in the cultivation of apples, pears, peaches (Prunus persica), grapes (Vitis vinifera), and loquats (Eriobotrya japonica) in Japan,
Australia, China, and the United States (Feng et al., 2014; Sharma et al., 2014; Zhou et al., 2019). Countries such as Mexico, Chile, and Argentina require certain fruits to be bagged during growth and development for some export markets (Sharma et al., 2014). Although bagging is a common practice that is useful, its effectiveness depends on the type of bag used, the stage of fruit development when bagged, its duration, the extent of fruit exposure to natural sunlight after bag removal, and fruit or cultivar-specific responses (Chen et al., 2012; Huang et al., 2009). Previous studies focused on the quality of bagged fruit at harvest, but little has been reported regarding the effect of bagging on postharvest quality and storability or shelf life of the fruit. Therefore, there is a need for further research to standardize specific bagging materials, how and how long they are used, and the subsequent postharvest quality of bagged fruit. This study reviewed the efficacy of preharvest bagging for enhancing the external, physicochemical, and phytochemical quality of several export-oriented fruits.

\section{Bagging materials}

The materials commonly used in the production of fruit bags include kraft-type paper, baking paper, polyethylene, microperforated polypropylene, and polypropylene spunbond fabrics (PSF) (Abbasi et al., 2014; Bilck et al., 2011; Liu et al., 2015; Zhou et al., 2019). Bags are produced in various colors and designs, with the ultimate aim of optimizing their suitability for fruit production (Muchui et al., 2010). In addition to physical protection, bagging has been used to protect individual fruit or bunches or clusters of fruit from low temperatures, especially in temperate regions (Harhash and Al-Obeed, 2010; Rajametov, 2017). Bagging has also been proven to reduce the stress of inclement temperatures on fruit growing in winter, leading to early fruit maturation (Mohamed and Al-Qurashi, 2012; Muchui et al., 2010).

Temperature. Low temperatures for example, those below $13{ }^{\circ} \mathrm{C}$, can cause peel discoloration and uneven ripening, especially in bananas (Musa acuminata), such that fruit is not acceptable to the export market (Hailu et al., 2013; Snowden,
2010). Low temperatures may also delay growth, thus extending the period between flowering and harvesting (Hailu et al., 2013; Vargas et al., 2010). To avoid these handicaps, preharvest bagging has been proposed as a means of improving the environmental conditions of fruit to promote their growth and development. Bagging mainly changes the light levels, temperature, and humidity around the enclosed fruit, resulting in various phytochemical changes in the product (Guo et al., 2019). Bag materials affect light transmission through the bags to the enclosed fruit and may affect fruit color development (Santosh et al., 2017). Transparent bags let in more light than those that are a translucent blue or green. However, blue bags, especially in banana-producing regions, are mostly used for fruit because they transmit heat without causing sun scald due to their ability to block ultraviolet light (Muchui et al., 2010). Transparent bags can be coated to block ultraviolet and infrared (IR) radiation. Bags that transmit ultraviolet and IR radiation improve the light and temperature conditions for fruit growth (Muchui et al., 2010; Santosh et al., 2017).

Transparent and perforated polythene bags with $2 \%$ to $4 \%$ ventilation (used during cool and summer seasons, respectively) avoid high relative humidity, which may result in high percentages of bacterial soft rots (Erwinia carotovora), uneven ripening, and proliferation of fungi (Muchui et al., 2010; Vargas et al., 2010). The use of white bags to reflect direct solar radiation also lowers the temperature inside the bags (Muchui et al., 2010). Furthermore, sunburn damage on the peel caused by high temperatures, which can reach more than $38{ }^{\circ} \mathrm{C}$, can be avoided through the use of perforated and reflective silver bags or ones with a reflective coating on one side (Turner, 2013).

The most preferred bagging materials are white, nonwoven polypropylene (Liu et al., 2015), transparent polypropylene with microperforations (Coelho et al., 2008; Karajeh, 2018), single-layer yellow materials (Zhou et al., 2019), and those with reflective films (Binbin et al., 2015) for enhancing anthocyanin content and peel color of peaches (Liu et al., 
2015; Zhou et al., 2019). Furthermore, plastic bags were recommended for enhancing the fruit size and soluble solids content in carambola [Averrboa carambola (Xu et al., 2008)]. Two-layer paper bags such as Haoguo (Guangzhou Huacai Plastic Bag Product Co., Guangzhou, China) have been recommended for soluble solids, anthocyanin content, color, and firmness improvements and lower acid content in pears (Lin et al., 2008).

Microclimate. Bagging creates a microclimate that maintains a relatively high temperature around the fruit, thereby preventing frost damage (Santosh et al., 2017). The temperature inside a bag increases, on average, by 1 to $2{ }^{\circ} \mathrm{C}$ in winter and 3 to $6{ }^{\circ} \mathrm{C}$ in summer (Omar et al., 2014; Santosh et al., 2017). This microclimate can reduce the flowerto-harvest interval period by 4 tol 4 $\mathrm{d}$ and increase the fruit or bunch weight and length (Omar et al., 2014). In the bag, relative humidity remains, on average, above $95 \%$, carbon dioxide $\left(\mathrm{CO}_{2}\right)$ varies widely from $<1 \%$ to $42 \%$, and oxygen $\left(\mathrm{O}_{2}\right)$ ranges from $2 \%$ to $19 \%$, which can be reduced by the use of perforated bags that also serve to prevent fungal diseases (Muchui et al., 2010). The size of the holes used varies; they can be $12.7 \mathrm{~mm}$ at intervals of $76 \mathrm{~mm}, 6 \mathrm{~mm}$ every $10 \mathrm{~cm}$, or $3 \mathrm{~mm}$ or microperforations, depending on the prevailing climatic conditions (Santosh et al., 2017).

A D V A N T A G E S A N D CHARACTERISTICS OF PLASTIC BAGS. Plastic bags have been widely recommended for preharvest bagging compared with paper bags (Coelho et al., 2008). Plastic has the ability to withstand wind and prevent rain or hail damage and achieve positive results by improving fruit quality and yield by mitigating extreme weather changes, bringing on harvests and reducing reliance on pesticides (Binbin et al., 2015; Kyrikou and Briassoulis, 2007). Most preharvest plastic bagging materials consist of polypropylene, which is commonly used due to its good mechanical and optical properties, thermal and chemical resistance, and competitive price (Chattopadhyay et al., 2008; Kyrikou and Briassoulis, 2007; Liu et al., 2015).

BAgGING AND DEBAGgING. Bagging is usually applied during flowering (Karajeh, 2018; Sharma et al., 2013), fruit set (Islam et al., 2019; Morera-Montoya et al., 2010), and early stages of fruit growth and development (Santosh et al., 2017; Rubel et al., 2019), whereas the debagging period varies with the fruit type (Islam et al., 2017; Liu et al., 2015; Schupp et al., 2002; Sharma et al., 2014). Previous studies have reported that removing bags from the individual fruit or bunch on the day of harvest inhibits color development, primarily because bagging partially blocks prevailing light levels, which are required for color pigment synthesis such as chlorophyll, lycopene, and anthocyanin (Feng et al., 2014; Zhou et al., 2019). According to Binbin et al. (2015) and Liu et al. (2015), removing bags from peaches 3 to $7 \mathrm{~d}$ before the time of harvest reexposes the fruit to sunlight, thereby promoting anthocyanin synthesis, which is responsible for color development in many red, purple and blue fruits, including apples, red pears, strawberries, grapes, blueberries (Vaccinium sp.), bayberries (Myriea cerifera), and peaches. Hirst et al. (1990) reported that bagging 'Granny Smith' apples with opaque paper bags beginning from fruit drop until commercial harvest and re-exposing fruit to a high light environment for 1 month or more significantly enhanced peel color by promoting degreening (chlorophyll degradation) as fruit increasingly became yellower.

\section{The influence of preharvest bagging on fruit quality}

Preharvest bagging has been used mainly for apples (Feng et al., 2014; Sharma et al., 2013), peaches (Liu et al., 2015; Zhou et al., 2019), mangoes (Chonhenchob et al., 2011; Islam et al., 2017), bananas (Muchui et al., 2010; Santosh et al., 2017), litchis [Litchi chinensis (Debnath and Mitra, 2008)], loquats (Xu et al., 2010), and dates [Phoenix dactylifera (Omar et al., 2014)] to improve fruit quality in terms of appearance, maturity, ripeness, peel color, firmness, sugar content, and antioxidants (Liu et al., 2015; Qin et al., 2012). The physical appearance of the peel, including its size, shape, color, gloss, and freedom from defects and decay, is extremely important in the highly competitive export markets and some local markets (Islam et al., 2017;
Kassem et al., 2011; Qin et al., 2012). In these prime outlets, buyers require consistent supplies of uniform fruit with blemish-free peels (Santosh et al., 2017). Inability to meet these demands may result in the loss of market access and consequent economic decline (Kassem et al., 2011; Liu et al., 2015). Therefore, several factors affect fruit appearance, including pest infestation, bird attacks, pathogens, physiological disorders, and mechanical damage, which leave bruises and wounds (Sharma et al., 2014; Zhou et al., 2019).

Pests responsible for major economic losses in fruit production include fruit flies and thrips (Thysanoptera) (Hamby et al., 2016; Tochen et al., 2014). These pests are known to feed on fruit, thereby causing silvering, hardening, pale yellowing, and browning of the peel, as well as elongated and patchy scars on the fruit peel (Affandi et al., 2008). Such fruit with blemishes and spots that may cover the entire peel surface are totally unacceptable, especially to the export market that has high quality standards (Affandi et al., 2008; Santosh et al., 2017).

Although researchers and agricultural and farming collectives offer insightful guidance regarding pest management, the recommended options are limited to the use of natural enemies, weeding under the canopy to eradicate alternative hosts such as weeds, regular pruning of heavily pest-infested trees, application of fluorescent yellow sticky traps, use of reflective mulch to disturb the host plant orientation of the insects, and application of agrochemicals (Affandi et al., 2008). Synthetic insecticides are used as another alternative when other control methods are not adequate. Although the application of insecticides is a worldwide practice and effective, it could be laborious and costly for use on a commercial scale (Affandi et al., 2008; Hilje et al., 2001). Schnitkey and Lattz (2008) reported that the unit cost per pesticide application and machinery cost was $\approx \$ 20.38 / \mathrm{h}$ and that the fuel cost was $\$ 12.38 / \mathrm{h}$ in agricultural commercial fields. Machinery repairs, maintenance, depreciation, and interest rates were estimated at $\$ 8 / \mathrm{h}$ (West et al., 2012). The labor cost for pesticide application (tractor 
driver) was set at $\$ 15.95 / \mathrm{h}$, which was assumed to be $10 \%$ higher than the accepted labor rate of $\$ 14.50 / \mathrm{h}$ (Schnitkey and Lattz, 2008). This is extremely expensive compared with other controls such as biological control. Gallardo et al. (2016) estimated that the costs of average pest management and secondary control using natural enemies (NE) such as codling moth (Cydia pomonella) mating disruption in favorable $\mathrm{NE}$ apple and pear orchards were $\$ 411 \pm \$ 85$ and $\$ 11 \pm \$ 34$ per hectare and $\$ 1647 \pm$ $\$ 269$ and $\$ 188 \pm \$ 133$ per hectare, respectively. In addition to the high cost of pesticides, Gallardo et al. (2016) reported that for every $\$ 1$ spent on high-risk pesticides, an extra $\$ 0.46$ was required for secondary pest control costs for both apple and pear orchards.

The EU has strictly limited the use of many agrochemicals such as insecticides due to their adverse impact on environmental and human health (Affandi et al., 2008; Masia et al., 2014). The need for an alternative method that is chemical-free has resulted in the practice of preharvest bagging to minimize quality defects, especially those caused by insect pests (Abbasi et al., 2014; Islam et al., 2017; Liu et al., 2015). Tables $\mathrm{l}$ and 2 show the success of bagging for controlling the incidence of insect pests and diseases, respectively, of selected fruits that had a significantly improved visual appearance. For example, Rosângela et al. (201la, $2011 \mathrm{~b}$ ) reported that bagging apples $40 \mathrm{~d}$ after flowering using transparent microperforated plastic or nontextured fabric bags effectively controlled fruit fly, oriental fruit moth (Grapholita molesta), apple leafroller (Bonagotasa lubricola), and woolly apple aphid (Eriosoma lanigerum) compared with control. Ko et al. (2010), Pandey and Tandon (2004), and Senghor et al. (2007) demonstrated that preharvest bagging of loquat and mango during growth and development using plastic and white and brown paper bags significantly reduced fruit rot (Alternaria sp.), anthracnose (Colletotrichum gloeosporioides), and stem-end rot (Dothiorella sp.) (Table 2). Most importantly, preharvest bagging also modifies the microenvironment of fruit during critical stages of growth and development, further enhancing fruit chemical quality such as antioxidants, which are beneficial for human health (Purbey and Kumar, 2015; Wang et al., 2010).

FRUIT MATURITY AND RIPENING. Preharvest bagging has been adopted in fruit farming for enhancing and accelerating maturity, the ripening process, and the pigments involved, which are also responsible for peel color change, such as lycopene, carotenoids, and anthocyanin, by improving the fruit microenvironment during the bagging period (Islam et al., 2017; Kayesh et al., 2013; Wang et al., 2010). Liu et al. (2015) reported that preharvest bagging using yellow paper and nonwoven

Table 1. The effect of preharvest bagging on controlling the incidence of insect pests on different fruits.

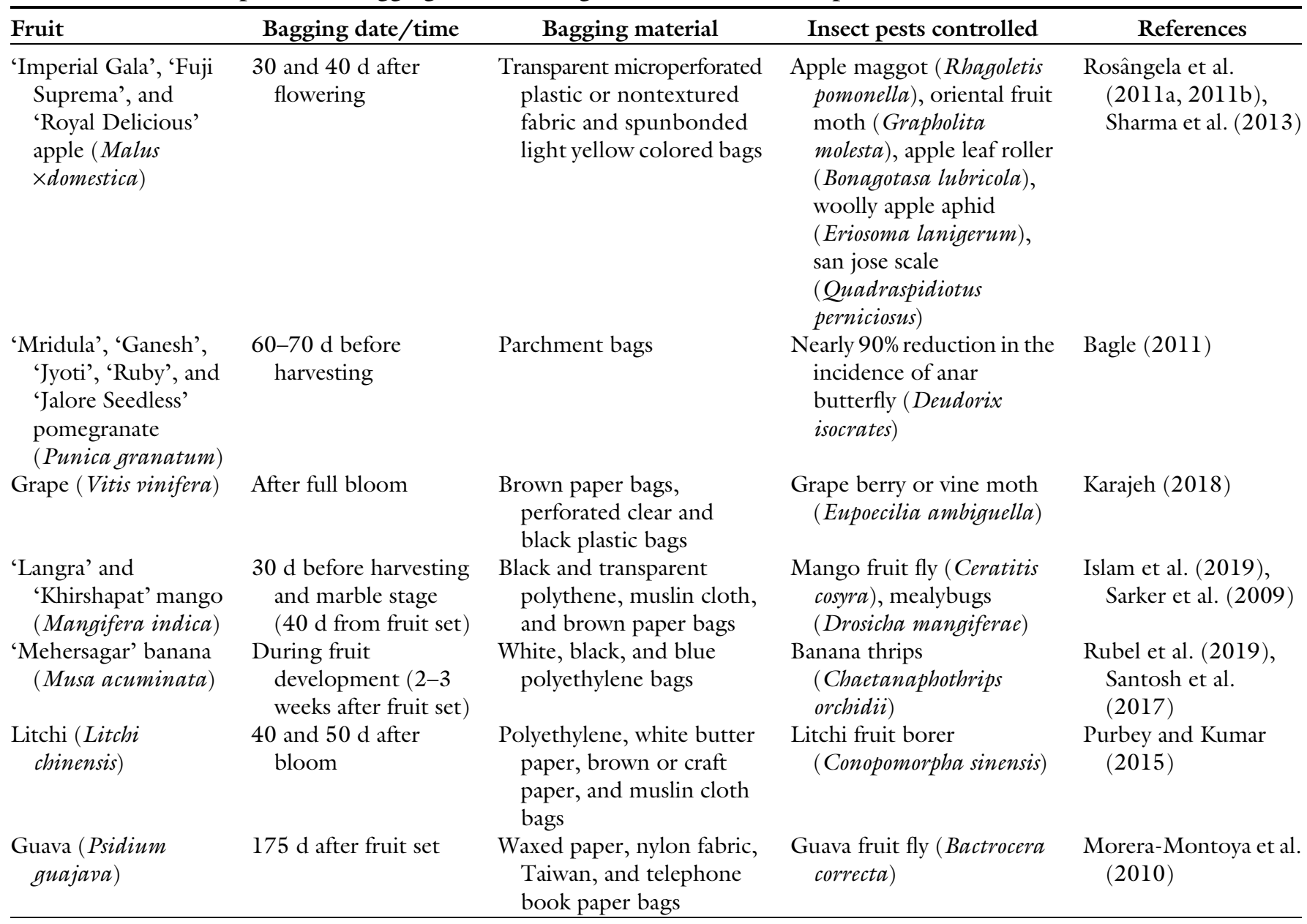


Table 2. The effect of preharvest bagging on controlling the incidence of diseases on different fruits.

\begin{tabular}{|c|c|c|c|c|}
\hline Fruit & $\begin{array}{c}\text { Bagging } \\
\text { date/time }\end{array}$ & Bagging material & Insects and diseases controlled & References \\
\hline $\begin{array}{l}\text { Guava (Psidium } \\
\text { guajava) }\end{array}$ & $\begin{array}{l}1 \text { month before } \\
\text { harvesting }\end{array}$ & Paper bags & $\begin{array}{l}\text { Reduction of black spot (Guignardia } \\
\text { psidii) and anthracnose } \\
\text { (Colletotrichum gloeosporioides) }\end{array}$ & Martins et al. (2007) \\
\hline $\begin{array}{l}\text { Loquat (Eriobotrya } \\
\text { japonica) }\end{array}$ & $\begin{array}{l}\text { During fruit } \\
\text { development }\end{array}$ & Plastic & Reduction of fruit rot (Alternaria sp.) & Ko et al. (2010) \\
\hline $\begin{array}{l}\text { 'Dashehari' mango } \\
\text { (Mangifera } \\
\text { indica) }\end{array}$ & $\begin{array}{l}\text { During fruit } \\
\text { development }\end{array}$ & $\begin{array}{l}\text { White and brown paper } \\
\text { bags }\end{array}$ & $\begin{array}{l}\text { Significant reduction of anthracnose } \\
\text { and stem-end rot (Dothiorella sp.) }\end{array}$ & $\begin{array}{l}\text { Pandey and Tandon } \\
\text { (2004), Senghor } \\
\text { et al. (2007) }\end{array}$ \\
\hline $\begin{array}{l}\text { Grape (Vitis } \\
\text { vinifera) }\end{array}$ & $\begin{array}{l}\text { After full } \\
\text { bloom }\end{array}$ & $\begin{array}{l}\text { Brown paper and } \\
\text { perforated clear and } \\
\text { black plastic bags }\end{array}$ & $\begin{array}{l}\text { Decreased black mold (Aspergillus } \\
\text { niger), gray molds (Botrytis } \\
\text { cinerea), and powdery mildew } \\
\text { (Uncinula necator) }\end{array}$ & Karajeh (2018) \\
\hline $\begin{array}{l}\text { 'Dwarf Cavendish' } \\
\text { banana (Musa } \\
\text { acuminata) }\end{array}$ & $\begin{array}{l}2 \text { to } 3 \text {-week-old } \\
\text { bunches }\end{array}$ & Polyethylene bags & $\begin{array}{l}\text { Decreased banana pitting (Pyricularia } \\
\text { grisea), fingertip end rot } \\
\text { (Pseudomonas sp.), cigar end rot } \\
\text { (Verticillium theobromae), brown } \\
\text { spot (Cercospora hayi), and } \\
\text { diamond spot (Cercospora hayi, } \\
\text { Fusarium sp.) }\end{array}$ & $\begin{array}{l}\text { Amani and Avagyan } \\
\qquad(2014)\end{array}$ \\
\hline $\begin{array}{l}\text { 'Royal Delicious' } \\
\text { apple (Malus } \\
\text { ×domestica) }\end{array}$ & $\begin{array}{l}30 \text { d before } \\
\text { harvesting }\end{array}$ & $\begin{array}{l}\text { Spunbonded light } \\
\text { yellow bags }\end{array}$ & $\begin{array}{l}\text { Reduced apple fly speck } \\
\text { (Schizothyrium pomi) and sooty } \\
\text { blotch (Phyllachora pomigena) }\end{array}$ & Sharma et al. (2013) \\
\hline
\end{tabular}

polypropylene bags significantly improved maturity, red color, and the anthocyanin content of peach peel compared with control. Chonhenchob et al. (2011) and Islam et al. (2017) reported that bagging mango using brown and white paper, muslin cloth, and wavelengthselective (ultraviolet-transparent) plastic bags significantly improved the $\beta$-carotene content, which is responsible for peel color, compared with control (Table 2).

FruIT COLOR. Fruit color is a principal point of attraction for the consumers who buy the products (Purbey and Kumar, 2015; Sharma et al., 2013). Hence, the preharvest bagging practice has been adopted to improve the visual quality of fruit by promoting peel coloration (Jakhar and Pathak, 2016). Preharvest bagging promotes the light sensitivity of fruit and stimulates pigments responsible for peel color, such as chlorophyll, carotenoids, and anthocyanin synthesis, when fruit are re-exposed to light for certain amounts of time after bag removal, leading to enhanced coloration (Kim et al., 2010; Purbey and Kumar, 2015; Zhang et al., 2013). For example, Sun et al. (2014) reported that after re-exposure to sunlight for $9 \mathrm{~d}$ before harvesting, 'Golden Delicious' apples bagged with light impermeable double-layer paper bags for $128 \mathrm{~d}$ significantly synthesized an increased amount of anthocyanin compared with unbagged fruit. Sharma et al. (2013) reported that bagging apples with spunbonded and light yellow fabric bags significantly enhanced peel color compared with control. Zhang et al. (2015) reported that bagging peaches using white and black single-layer paper bags and white single-layer polypropylene nonwoven bags significantly improved peel color as a result of enhanced anthocyanin content compared with control (Table 3).

FRUit FIRMNESS AND WEIGHT. The preharvest bagging technique has been used at some developmental stages for enhancing fruit physiology, thus directly or indirectly contributing to the growth and size of the product (Sharma and Sanikommu, 2018). Harhash and Al-Obeed (2010) reported that bagging date palm with black, white, blue, and yellow plastic bags effectively accelerated fruit maturity and ripening and increased fruit weight, length, and diameter compared with control. Sharma et al. (2013) reported that bagging apples with spunbonded light yellow fabric bags significantly enhanced fruit firmness and color at harvest and during postharvest storage of 6 months at $2{ }^{\circ} \mathrm{C}$ compared with control. Abbasi et al. (2014) demonstrated that bagging guava (Psidium guajava) using newspaper bags effectively enhanced fruit firmness at harvest and during postharvest storage of $15 \mathrm{~d}$ at $15{ }^{\circ} \mathrm{C}$ compared with control (Table 3 ).

PRIMARY AND SECONDARY METABOLITES. Preharvest bagging may significantly improve the concentration of total soluble sugars (Abbasi et al., 2014; Islam et al., 2017) by enhancing respiration and ethylene production rates, thus reducing titratable acids as a result of accelerated maturity and ripening (Feng et al., 2014; Sharma et al., 2014; Zhang et al., 2010). Also, preharvest bagging may enhance the biosynthesis of secondary metabolites such as antioxidant activity, phenols, flavonoids, anthocyanin, chlorophyll, and carotenoids, which are a necessity for fruit coloration (Feng et al., 2014; Harasym and Oledzki, 2014; Huang et al., 2009; Kayesh et al., 2013; Sharma et al., 2014). Table 3 shows the ability of preharvest bagging to enhance these compounds and the overall quality of selected fruits. For example, Hudima and Stamper (2011) and Lin et al. (2012) reported that preharvest bagging of pear using triple-layer 
Table 3. Influence of preharvest bagging on fruit quality.

\begin{tabular}{|c|c|c|c|}
\hline Fruit & Best recommended bag material & Reported positive influence & References \\
\hline Palm & Black, white, blue, and yellow plastic bags & $\begin{array}{l}\text { Accelerated maturity and ripening, } \\
\text { increased fruit weight, length, and } \\
\text { diameter }\end{array}$ & Harhash and Al-Obeed (2010) \\
\hline Mango & $\begin{array}{l}\text { Brown and white paper, muslin cloth, } \\
\text { wavelength-selective plastic (e.g., } \\
\text { ultraviolet-transparent plastics) }\end{array}$ & $\begin{array}{l}\text { Increased fruit length, weight, diameter, } \\
\text { total soluble solids, citric acid, reduced } \\
\text { sugar, total sugar, and } \beta \text {-carotene contents }\end{array}$ & $\begin{array}{l}\text { Chonhenchob et al. (2011), } \\
\text { Islam et al. (2017) }\end{array}$ \\
\hline
\end{tabular}

white, black, and grey paper bags significantly enhanced soluble solids and phenolic compounds compared with control. Liu et al. (2015), Zhang et al. (2015) and Zhou et al. (2019) demonstrated that preharvest bagging of peach using white nonwoven polypropylene bags, transparent microperforated polypropylene, single-layer yellow paper bags, and reflective silver films significantly enhanced anthocyanin content compared with control. Another study by Islam et al. (2017) demonstrated bagging mango using brown and white paper, muslin cloth, and wavelength-selective (ultraviolet-transparent) plastic bags effectively enhanced $\beta$-carotene content compared with control (Table 3 ).

\section{Economic impact and cost- benefit ratio of preharvest bagging}

In the horticultural industry, more than $50 \%$ of the production volume is affected by fruit fly, among other pests. Fruit fly may cause, for example, fruit injury or scaring, rotting, and susceptibility to pathogens, which lead to heavy losses of yield and quality (Badii et al., 2015). Yield loss due to fruit fly damage has been reported to be $\approx 70 \%$ for mango and $40 \%$ for citrus fruits (Citrus sp.) (Badii et al., 2015 ). Leach et al. (2018) reported that economic losses due to spottedwing drosophila (Drosophila suzukii) in the western United States for raspberry, blackberry (Rubus fruticosus), blueberry, strawberry, and sweet cherry (Prunus avium) are estimated to be more than $\$ 500$ million annually. The aforementioned problem is mostly managed by the application of pesticides on commercial farms (Leach et al., 2018; Masia et al., 2014). However, due to the costs of material and labor, environmental and health hazards to consumers, and limitations to and prohibition of synthetic pesticides in organic agriculture, global awareness and efforts for the development of nonchemical alternatives, such as preharvest bagging to reduce pests and disease infestation, are increasing (Diepenbrock et al., 2016; Leach et al., 2018).

Preharvest bagging is one of the most effective nonchemical alternatives and is a substitute for pesticides (Liu et al., 2015; Sharma and Sanikommu, 2018). It is economically effective because it reduces the cost of production, particularly that of organic production of fruit, thus increasing the net profit and easy-to-use practice, breaking the financial and educational barriers of farmers, and promoting further expansion in organic fruits (Karajeh, 2018). Fallahi et al. (2001) reported that 'BC-2 Fuji' apples bagged with double-layer paper bags (outer layer: gray outside, black inside; inner layer: red) had significantly higher nitrogen, potassium, and copper contents compared with the chemical method. A study by Filgueiras et al. (2017) demonstrated an average cost reduction of $40.7 \%$ $(\$ 11,236)$ per hectare for tomato
(Solanum lycopersicum) fruit bagged with nonwoven fabric bags compared with chemical control. The authors stated that with the conventional system, manual labor plus insecticides would cost $\approx \$ 27,556 /$ ha; however, with the bagging system, manual labor plus bagging with nonwoven fabric bags would cost $\approx \$ 16,320 /$ ha. Another study by Afsar and Sultana (2019) showed that adopters of bagging technology in mango production using brown paper doublelayer bags, white paper single-layer bags, perforated polythene, and muslin cloth bags had significantly higher yields of $10,850 \mathrm{~kg}$, gross return of $\$ 7031.62$, and net return of $\$ 5077.49$ compared with nonadopters, who had an average yield of 8250 $\mathrm{kg}$, gross return of $\$ 3888.45$, and net return of $\$ 2698.94$ per hectare. With higher production and price, bagging technology adopters had a higher benefit-cost ratio (3.59) than nonadopters (3.26) (Afsar and Sultana, 2019). Therefore, preharvest bagging is an economically viable technique for fruit protection that improves fruit external quality and internal quality and reduces or eliminates the excessive application of pesticides.

\section{Future prospects}

Previous research of preharvest bagging to enhance fruit quality has mainly focused on inspecting the quality at harvest; very few studies have reported the effects of preharvest bagging on postharvest fruit quality and storability (Kireeti et al., 2016; Sharma et al., 2013). Therefore, 
future studies should investigate the impact of preharvest bagging on postharvest fruit quality. This review has shown that the effect of preharvest bagging is mostly influenced by factors such as type of bag used, fruit development when bagged, bagging duration, and fruit exposure to natural sunlight after bag removal (Chen et al., 2012; Huang et al., 2009). Some previous studies have recommended the use of plastic bags because of their ability to improve fruit quality and because they are reusable under most weather conditions, although their resistance to degradation presents disposal problems when their usefulness ceases. Although there are recycling plants in operation that process the plastic waste, mechanical recycling may consume more energy in the long-term than making the same product from virgin polymers (Kyrikou and Briassoulis, 2007; Liu et al., 2015). Also, plastic residues remain in the soil for years, and large pieces are not only an impediment to plant growth but also a potential hazard to animals if the land is subsequently put down to grass (Islam et al., 2017; Scott, 2005; Sharma et al., 2013).

The use of paper bags has also been proven to be capable of improving fruit quality, but they are prone to wind damage and rain damage, which destroy the bags, thus allowing insects to access and damage the fruit during developmental stages (Lin et al., 2012; Xu et al., 2010; Zamora et al., 2008). Despite these challenges and the labor-intensive and economic costs of preharvest bagging, it has become an important part of the commercial culture of apples, pears, peaches, and loquats in countries such as Japan, China, and the United States (Feng et al., 2014; Liu et al., 2015; Xu et al., 2010). The benefits of preharvest bagging remain to be promoted globally. Cost-benefit analyses should be performed to confirm the research and support its worldwide adoption.

The development and recommendation of effective biodegradable bags are required (Islam et al., 2017; Sharma et al., 2013). Biodegradable bags made of polyolefin plastic completely decompose in time through the action of naturally occurring microorganisms (Cheong et al., 2010). Also, decomposition can be influenced by controlled degradation through the incorporation of prodegradants, such as cobalt or manganese stearate, and undergo accelerated oxidation or degradation initiated by natural light, heat, and oxygen (Cheong et al., 2010; Yossathorn and Jutarat, 2015). Furthermore, the manufacture of biologically based polymers to conserve petrochemical resources and minimize environmental impact includes plant-based products made from sago derived from starch and natural fiber (Chandima and Jayasuriya, 2015; Cheong et al., 2010), disposable foam food containers using starch and nanoclay (Basilla, 2011), biodegradable products made from cassava (Manihot esculenta) starch, mulching film, and bags made of corn (Zea mays) starch and oil derivatives (Gutierrez et al., 2015; Obasi and Igwe, 2014; Yossathorn and Jutarat, 2015).

Completely biodegradable starchbased polymers are promising materials for several applications, and their development might be an alternative solution for reducing the consumption of petroleum resources and environmental problems (Lu et al., 2009). They can completely decompose within 3 months to 5 years, depending on the material used (Chandima and Jayasuriya, 2015; Yossathorn and Jutarat, 2015 ). Moreover, the potential of biodegradable plastic material is realized by mixing cassava starch and polybutylene succinate. Cassava starch is cheap and considered waste in potato (Solanum tuberosum) chips processing, widely available, and relatively easy to handle, whereas polybutylene succinate has several desirable properties such as biodegradability, thermoplastic processability, and versatile mechanical properties (Xu and Guo, 2010).

Among the main benefits of using lignocellulosic or agricultural fibers as fillers or reinforcements in plastics are their low densities, nonabrasive character, high filling levels possibly resulting in high stiffness properties, easily recyclability, biodegradability (the wide variety of fibers available throughout the world would generate rural jobs and boost nonfood agricultural and farm-based economies), low energy consumption, and cost (Ahmad et al., 2015; Dittenber and GangaRao, 2012). However, although attempts have been made to produce biodegradable polymers, little has been reported regarding their use for preharvest fruit bagging. Therefore, future research is necessary to critically examine the use of biodegradable plastic materials for this purpose.

\section{Conclusion}

Although preharvest bagging is a simple and grower-friendly technique that is safe to use and has several beneficial effects on the physical appearance and chemical quality of tree fruit, it is an expensive practice for large-scale production $(\approx \$ 16,320 /$ ha). However, farmers can reduce production costs and increase productivity and profit by more than $90 \%$ per hectare. Furthermore, it is an effective alternative to replacing the use of agrochemicals - fungicides and insecticides that can threaten the safety of workers in the horticultural industry and the health of consumers. Any food sample, especially unprocessed fruit, is prone to containing pesticide residues because they are widely dispersed from their application areas. Many studies have recommended the use of plastic bags; therefore, there is a need to develop and test biodegradable bags that decompose after use. There is also a need for future research to standardize specifications for the most effective types of bag to be used and to determine the optimum bagging and debagging timetables for growers to benefit from this technology.

\section{Literature cited}

Abbasi, N.A., M.A. Chaudhary, M.I. Ali, A. Hussain, and I. Ali. 2014. On tree fruit bagging influences quality of guava harvested at different maturity stages during summer. Intl. J. Agr. Biol. 16:543-549.

Affandi, A., D. Emilda, and M. Jawal A.S. 2008. Application of fruit bagging, sanitation, and yellow sticky trap to control thrips on mangosteen. Indones. J. Agr. Sci. 9:19-23.

Afsar, M. and N. Sultana. 2019. Effects of different bagging materials on mango production: Assessment of profitability and fruit quality. J. Agr. Rural Res. 4:1-11.

Ahmad, F., H.S. Choi, and M.K. Park. 2015. A review: Natural fiber composites selection in view of mechanical, light weight, and economic properties. Macromol. Mater. Eng. 300:10-24.

Amani, M. and G. Avagyan. 2014. Effect of polyethylene bunch cover on fungal 
diseases control of banana (Musa acuminata L.) in Iran. Intl. J. Farm. Alli. Sci. 3:1054-1057.

Asplen, M., G. Anfora, A. Biondi, D. Choi, D. Chu, K. Daane, P. Gibert, A. Guiterrez, K. Hoelmer, W. Hutchison, R. Isaacs, Z. Jiang, Z. Karpati, M. Kimura, M. Pascual, C. Phillips, C. Plantamp, L. Ponti, G. Vetek, H. Vogt, V. Walton, Y. Yu, L. Zappala, and N. Desneux. 2015. Invasion biology of spotted wing drosophila (Drosophila suzukii): A global perspective and future priorities. J. Pest Sci. 88:469-494.

Badii, K.B., M.K. Billah, K. Afreh-Nuamah, D. Obeng-Ofori, and G. Nyarko. 2015. Review of the pest status, economic impact and management of fruit-infesting flies (Diptera: Tephritidae) in Africa. Afr. J. Agr. Res. 10:1488-1498.

Bagle, B.G. 2011. Studies on varietal reaction, extent of damage and management of anar butterfly, Deudorix (=Viracola) isocrates Fab. in pomegranate. Acta Hort. 890:557-559.

Basilla, B.A. 2011. Green packaging films. Ind. Technol. Dev. Inst., Dept. Sci. Technol., Philsprint Publ., Taguig City, Philippines.

Bilck, A.P., S.R. Roberto, M.V.E. Grossmann, and F. Yamashita. 2011. Efficacy of some biodegradable films as pre-harvest covering material for guava. Scientia Hort. 130:341-343.

Binbin, Z., M. Ruijuan, Z. Chunhua, C. Zhixiang, and Y. Zhimei. 2015. Effect of bag removing with reflective film mulching before harvest on fruit coloration and expression of anthocyanin related genes in peach. Hort. Plant J. 1:139-146.

Biondi, A., V. Mommaerts, G. Smagghe, E. Viñuela, L. Zappalà, and N. Desneux. 2012. The non-target impact of spinosyns on beneficial arthropods. Pest Manag. Sci. 68:1523-1536.

Chandima, A.M.B. and C.K. Jayasuriya. 2015. Synthesis and characterization of biodegradable polymeric composites using locally available starch derivatives. Intl. J. Sci. Res. Innov. Technol. 2:65-76.

Chattopadhyay, J., C. Kim, R. Kim, and D. Pak. 2008. Thermogravimetric characteristics and kinetic study of biomass co-pyrolysis with plastics. Korean J. Chem. Eng. 25:1047.

Chen, C.S., D. Zhang, Y.Q. Wang, P.M. Li, and F.W. Ma. 2012. Effects of fruit bagging on the contents of phenolic compounds in the skin and flesh of 'Golden Delicious', 'Red Delicious', and 'Royal Gala' apples. Scientia Hort. 142:68-73.

Cheong, K.S., J.R. Balasubramaniam, Y.P. Hung, W.S. Chuong, and R. Amar- talingam. 2010. Development of biodegradable plastic composite blends based on sago derived starch and natural rubber. Pertanika J. Sci. Technol. 18:411-420.

Chonhenchob, V., D. Kamhangwong, J. Kruenate, K. Khongrat, N. Tangchantra, U. Wichai, and S.P. Singh. 2011. Preharvest bagging with wavelength-selective materials enhances development and quality of mango (Mangifera indica L.) cv. Nam Dok Mai \#4. J. Sci. Food Agr. 91:664-671.

Coelho, L.R., S. Leonel, W.B. Crocomo, and A.M. Labinas. 2008. Avaliação de diferentes materiais no ensacamento de pêssegos. Rev. Bras. Frutic. 30:822-826.

De Bon, H., J. Huat, L. Parrot, A. Sinzogan, T. Martin, E. Malezieux, and J.F. Vayssieres. 2014. Pesticide risks from fruit and vegetable pest management by small farmers in sub-Saharan Africa. A review. Agron. Sustain. Dev. 34:723-736.

Debnath, S. and S.K. Mitra. 2008. Panicle bagging for maturity regulation, quality improvement and fruit borer management in litchi (Litchi chinensis). Acta Hort. 773: 201-208.

Diepenbrock, L.M., D.O. Rosensteel, J.A. Hardin, A.A. Sial, and H.J. Burrack. 2016. Season-long programs for control of Drosophila suzukii in southeastern U.S. blueberries. Crop Prot. 81:76-84.

Dittenber, D.B. and H.V. GangaRao. 2012. Critical review of recent publications on use of natural composites in infrastructure. Compos., Part A Appl. Sci. Manuf. 43:1419-1429.

Fallahi, E., W.M. Colt, C.R. Baird, B. Fallahi, and I.J. Chun. 2001. Influence of nitrogen and bagging on fruit quality and mineral concentrations of ' $\mathrm{BC}-2$ Fuji' apple. HortTechnology 11:462-466.

Farnsworth, D., K.A. Hamby, M. Bolda, R.E. Goodhue, J.C. Williams, and F.G. Zalom. 2017. Economic analysis of revenue losses and control costs associated with the spotted wing drosophila, Dro sophila suzukii (Matsumura), in the California raspberry industry. Pest Manag. Sci. 73:1083-1090.

Feng, F., M. Li, F. Ma, and L. Cheng. 2014. The effects of bagging and debagging on external fruit quality, metabolites, and the expression of anthocyanin biosynthetic genes in 'Jonagold' apple (Malus domestica Borkh.). Scientia Hort. 165:123-131.

Filgueiras, R.M.C., P.L. Pastori, F.F. Pereira, C.R. Coutinho, S.O. Kassab, and L.C.M. Bezerra. 2017. Agronomical indicators and incidence of insect borers of tomato fruits protected with non-woven fabric bags. Cienc. Rural 47:1-6.
Gallardo, R.K., J.F. Brunner, and S. Castagnoli. 2016. Capturing the economic value of biological control in western tree fruit. Biol. Control 102:93-100.

Goodhue, R.E., M. Bolda, D. Farnsworth, J.C. Williams, and F.G. Zalom. 2011. Spotted wing drosophila infestation of California strawberries and raspberries: Economic analysis of potential revenue losses and control costs. Pest Manag. Sci. 67:1396-1402.

Guo, S.H., T.F. Xu, T.C. Shi, X.Q. Jin, M.X. Feng, X.H. Zhao, Z.W. Zhang, and J.F. Meng. 2019. Cluster bagging promotes melatonin biosynthesis in the berry skins of Vitis vinifera cv. Cabernet Sauvignon and Carignan during development and ripening. Food Chem. 305:1-9.

Gutierrez, R.M., S.M.M.V. Daupan, A.V. Fabian, and C.C. Miclat. 2015. Microbiological investigation on some biodegradable plastics used as packaging materials. Asian J. Appl. Sci. 3:75-81.

Hailu, M., T.S. Workneh, and D. Belew. 2013. Review on postharvest technology of banana fruit. Afr. J. Biotechnol. $12: 635-647$

Hamby, K.A., D.E. Bellamy, J.C. Chiu, J.C. Lee, V.M. Walton, N.G. Wiman, R.M. York, and A. Biondi. 2016. Biotic and abiotic factors impacting development, behavior, phenology, and reproductive biology of Drosophila suzukii. J. Pest Sci. 89:605-619.

Harasym, J. and R. Oledzki. 2014. Effect of fruit and vegetable antioxidants on total antioxidant capacity of blood plasma. Nutrition 30:511-517.

Harhash, M.M. and R.S. Al-Obeed. 2010. Effect of bunch bagging colour on yield and fruit quality of date palm. Amer.-Eurasian J. Agr. Environ. Sci. 7:312-319.

Hilje, L., H.S. Costa, and P.A. Stansly. 2001. Cultural practices for managing Bemisia tabaci and associated viral diseases. Crop Prot. 20:801-812.

Hirst, P.M., D.S. Tustin, and I.J. Warrington. 1990. Fruit colour responses of 'Granny Smith' apple to variable light environments. N. Z. J. Crop Hort. Sci. 18:205-214.

Huang, C., B. Yu, Y. Teng, J. Su, Q. Shu, Z. Cheng, and L. Zeng. 2009. Effects of fruit bagging on coloring and related physiology, and qualities of red chinese sand pears during fruit maturation. Scientia Hort. 121:149-158.

Hudima, M. and F. Stamper. 2011. Effect of fruit bagging on quality of 'Conference’ pear (Pyrus communis L.). Eur. J. Hort. Sci. 76:410-414. 
Islam, M.T., M. Shamsuzzoha, M.S. Rahman, M.M. Haque, and R. Alom. 2017. Influence of pre-harvest bagging on fruit quality of mango (Mangifera indica L.) cv. Mollika. J. Bios. Agr. Res. 15:1246-1254.

Islam, M.T., M.S. Rahman, M.M. Akter, M.N. Hasan, and M.S. Uddin. 2019. Influence of pre-harvest bagging on fruit quality of mango (Mangifera indica L.) cv. Langra. Asian J. Agr. Hort. Res. 4:1-10.

Jakhar, M.S. and S. Pathak. 2016. Effect of pre-harvest nutrients application and bagging on quality and shelf life of mango (Mangifera indica L.) fruits cv. Amrapali. J. Agr. Sci. Tech. 18:717-729.

Karajeh, M.R. 2018. Pre-harvest bagging of grape clusters as a non-chemical physical control measure against certain pests and diseases of grapevines. Org. Agr. 8:259-264.

Kassem, H.A., R.S. Al-Obeed, M.A. Ahmed, and A.K.H. Omar. 2011. Productivity, fruit quality and profitability of jujube trees improvement by preharvest application of agro-chemicals. Middle East J. Sci. Res. 9:628-637.

Kasso, M. and A. Bekele. 2018. Postharvest loss and quality deterioration of horticultural crops in Dire Dawa Region, Ethiopia. J. Saudi Soc. Agr. Sci. 17:88-96.

Kayesh, E., L. Shangguan, N.K. Korir, X. Sun, N. Bilkish, Y. Zhang, J. Han, C. Song, Z.M. Cheng, and J. Fang. 2013. Fruit skin color and the role of anthocyanin. Acta Physiol. Plant. 35:2879-2890.

Kim, Y.K., S.S. Kang, K.S. Cho, and S.B. Jeong. 2010. Effects of bagging with different pear paper bags on the color of fruit skin and qualities in 'Manpungbae'. Korean J. Hort. Sci. Technol. 28:36-40.

Kireeti, A., P.M. Haldankar, M.R.V. Babu, and Y.R. Parulekar. 2016. Effect of pre harvest bagging on mango fruit quality. Res. Environ. Life Sci. 9:13661369.

Ko, Y., C.W. Liu, S.S. Chen, C.Y. Chen, K.S. Yao, S. Maruthasalam, and C.H. Lin. 2010. First report of fruit rot of loquat caused by an Alternaria sp. in Taiwan. Plant Dis. 94:481-484.

Kyrikou, I. and D. Briassoulis. 2007. Biodegradation of agricultural plastic films: A critical review. J. Polym. Environ. 15:125-150.

Leach, H., J. Moses, E. Hanson, P. Fanning, and R. Isaacs. 2018. Rapid harvest schedules and fruit removal as non-chemical approaches for managing spotted wing drosophila. J. Pest Sci. 91: 219-226.
Lin, J., J.H. Wang, X.J. Li, and Y.H. Chang. 2012. Effects of bagging twice and room temperature storage on quality of 'Cuiguan' pear fruit. Acta Hort. 934: 837-840.

Lin, J., Y. Chang, Z. Yan, and X. Li. 2008. Effects of bagging on the quality of pear fruit and pesticide residues. Acta Hort. 772: 315-318.

Liu, T., S. Song, Y. Yuan, D. Wu, M. Chen, Q. Sun, B. Zhang, C. Xu, and K. Chen. 2015. Improved peach peel color development by fruit bagging. Enhanced expression of anthocyanin biosynthetic and regulatory genes using white nonwoven polypropylene as replacement for yellow paper. Scientia Hort. 184:142148.

Lu, D.R., C.M. Xiao, and S.J. Xu. 2009. Starch-based completely biodegradable polymer materials. Express Polym. Lett. 3:366-375.

Martins, M.C., A. Lilian, S.A. Lourenço, A.S. Gutierrez, and H.S. Watanabe. 2007. Incidence of post harvest damages in guavas at the wholesale market of São Paulo and its relationship to pre harvest bagging. Braz. Mag. Fruit Cult. 29:245248.

Masia, A., C. Blasco, and Y. Pico. 2014. Last trends in pesticide residue determination by liquid chromatographymass spectrometry. Trends Environ. Anal. Chem. 2:11-24.

Mohamed, A.A. and A.D. Al-Qurashi. 2012. Gibberellic acid spray and bunch bagging increase bunch weight and improve fruit quality of 'Barhee' date palm cultivar under hot arid conditions. Scientia Hort. 138:96-100.

Morera-Montoya, R., H. Blanco-Metzler, and C.R. Luis-Loria. 2010. Evaluation of different bagging materials for the control of the fruit fly Anastrepha sp. (Diptera, Tephritidae) and fruit pathogens in Taiwanese guava fruits (Psidium guajava L.). Acta Hort. 849:283-292.

Muchui, M.N., F.M. Mathooko, C.K. Njoroge, E.M. Kahangi, C.A. Onyango, and E.M. Kimani. 2010. Effect of perforated blue polyethylene bunch covers on selected postharvest quality parameters of tissue-cultured bananas (Musa spp.) cv. Williams in central Kenya. J. Stored Prod. Postharvest Res. 1:29-41.

Obasi, H.C. and I.O. Igwe. 2014. Effects of native cassava starch and compatibilizer on biodegradable and tensile properties of polypropylene. Amer. J. Eng. Res. 3:96-104.

Omar, A.E.D.K., A.M. Al-Saif, and M.A.E.A. Ahmed. 2014. Bagging of bunches with different materials in- fluences yield and quality of Rothana date palm fruit. J. Food Agr. Environ. 12:520522.

Pandey, B.K. and D.K. Tandon. 2004. Effect of bagging on incidence of post harvest disease and quality of 'Dashehari' mango fruits. First Indian Hort. Congress 722:348.

Pareja, L., A.R. Fernández-Alba, V. Cesio, and H. Heinzen. 2011. Analytical methods for pesticide residues in rice. TrAC Trend. Anal. Chem. 30:270-291.

Purbey, S.K. and A. Kumar. 2015. Effect of pre-harvest bagging on quality and yield of litchi (Litchi chinensis Sonn.) fruits. The Ecoscan: Intl. Quarterly J. Environ. Sci. 7:197-201.

Qin, S.J., F.D. Li, D.G. Lv, and W.S. Gao. 2012. Effect of preharvest bagging on fruit epidermis epiphyte community structure of 'Red Fuji' apple. Middle East J. Sci. Res. 12:1276-1281.

Rajametov, S. 2017. Effect of paper bag types on fruit physiology and quality of pear cultivar 'Packham's Triumph' during harvest and storage period. Genet. Plant Physiol. 7:89-104.

Rosângela, T., C.V.T. do Amarante, M.I.C. Boff, and L.G. Ribeiro. 2011 a. Control of insect pests and diseases, maturity and quality of 'Imperial Gala' apples submitted to bagging. Braz. Mag. Fruit Cult. 2:394-401.

Rosângela, T., M.I.C. Boff, C.V.T. do Amarante, C.A. Steffens, and P. Boff. $2011 \mathrm{~b}$. Effects of fruit bagging on pests and diseases control and on quality and maturity of 'Fuji Suprema' apples. Bragantia 70:688-695.

Rubel, M.H.K., M.M. Hossain, M.M.H. Hafiz, M.M. Rahman, and M.R. Khatun. 2019. Effect of banana bunch covering technology for quality banana production in Bangladesh. Progress. Agr. 30:238-252.

Santosh, D.T., K.N. Tiwari, and R.G. Reddy. 2017. Banana bunch covers for quality banana production - A review. Intl. J. Curr. Microbiol. Appl. Sci. 6:1275-1291.

Sarker, D., M.M. Rahman, and J.C. Barman. 2009. Efficacy of different bagging materials for the control of mango fruit fly. Bangladesh J. Agr. Res. 34:165-168.

Schnitkey, G. and D. Lattz. 2008. Farm business management machinery cost estimates: Tractors. Dept. Agr. Consumer Econ., Univ. Illinois, Urbana.

Schupp, J.R., E. Fallahi, and I.J. Chun. 2002. Effect of particle film on fruit sunburn, maturity and quality of 'Fuji' and 
'Honeycrisp' apples. HortTechnology 12:87-90.

Scott, G. 2005. Standards for environmentally biodegradable plastics. Woodhead Publ., Cambridge, UK.

Senghor, A.L., W.J. Liang, and W.C. Ho. 2007. Integrated control of Colletotrichum gloeosporioides on mango fruit in Taiwan by the combination of Bacillus subtilis and fruit bagging. Biocontrol Sci. Technol. 17:865-870.

Sharma, R.R. and V.R. Sanikommu. 2018. Preharvest fruit bagging for better protection and postharvest quality of horticultural produce, p. 455-489. In: M.W. Siddiqui (ed.). Preharvest modulation of postharvest fruit and vegetable quality. Academic Press, London, UK.

Sharma, R.R., D. Singh, and R. Singh. 2009. Biological control of postharvest diseases of fruits and vegetables by $\mathrm{mi}-$ crobial antagonists: A review. Biol. Control 50:205-221.

Sharma, R.R., R.K. Pal, R. Asrey, V.R. Sagar, M.R. Dhiman, and M.R. Rana. 2013. Pre-harvest fruit bagging influences fruit color and quality of apple cv. Delicious. Agr. Sci. 4:443-448.

Sharma, R.R., S.V.R. Reddy, and M.J. Jhalegar. 2014. Pre-harvest fruit bagging: A useful approach for plant protection and improved post-harvest fruit quality A review. J. Hort. Sci. Biotechnol. 89:101-113.

Snowden, A.L. 2010. A colour atlas of postharvest disease and disorders of fruits and vegetables. General introductions and fruits. Manson Publ., London, UK.

Sun, S., L. Xin, H. Gao, J. Wang, and P. Li. 2014. Response of phenolic compounds in 'Golden Delicious' and 'Red Delicious' apples peel to fruit bagging and subsequent sunlight re-exposure. Scientia Hort. 168:161-167.

Tochen, S., D.T. Dalton, N.G. Wiman, C. Hamm, P.W. Shearer, and V.M. Walton. 2014. Temperature-related development and population parameters for Drosophila suzukii (Diptera: Drosophilidae) on cherry and blueberry. Environ. Entomol. 43:501-510.

Turner, D.W. 2013. Crop physiology and cultural practices - A synergy in banana and plantain (Musa spp.). Acta Hort. 986: $41-50$

Tyagi, S., S. Sahay, M. Imran, K. Rashmi, and S.S. Mahesh. 2017. Pre-harvest factors influencing the postharvest quality of fruits: A review. Curr. J. Appl. Sci. Technol. 23:1-12.

Vargas, A., H. Valle, and M. González. 2010. Effect of color and density of polyethylene bunch covers on the dimensions, appearance and postharvest quality of banana and plantain fruits. Agron. Costarric. 34:269-285.

Wang, X., B. Hang, and C. Liu. 2010. Distribution of calcium in bagged apple fruit and relationship between antioxidant enzyme activity and bitter pit. Agr. Sci. Technol. 11:82-85.

West, T., R. Sullivan, C. Seavert, and S. Castagnoli. 2012. Enterprise budgets apples, medium density, north central region. Oregon State Univ. Ext. Factsheet AEB0024.

Wiman, N.G., D.T. Dalton, G. Anfora, A. Biondi, J.C. Chiu, K.M. Daane, B. Gerdeman, A. Gottardello, K.A. Hamby, R. Isaacs, and A. Grassi. 2016. Drosophila suzukii population response to environment and management strategies. J. Pest Sci. 89:653-665.

Xu, C.X., H.B. Chen, R.Y. Huang, and Y.J. He. 2008. Effects of bagging on fruit growth and quality of carambola. Acta Hort. 773:195-200.

Xu, H.X., J.W. Chen, and M. Xie. 2010 Effect of different light transmittance paper bags on fruit quality and anti-oxidant capacity in loquat. J. Sci. Food Agr. 90:1783-1788

Xu, J. and B.H. Guo. 2010. Poly (butylene succinate) and its copolymers: Research, development and industrialization. Biotechnol. J. 5:1149-1163.

Yossathorn, T. and P. Jutarat. 2015. Effect of starch types on properties of biodegradable polymer based on thermoplastic starch process by injection molding technique. Songklanakarin J. Sci. Technol. 37:193-199.

Zamora, N.F., R.S. Orquia, and H.G. Golez. 2008. Efficiency of DuPont Tyvek ${ }^{\circledR}$ bag as bagging material for mango fruits. Philsprint Publ., Guimaras, Philippines.

Zhang, B.B., J.Y. Guo, R.J. Ma, Z.X. Cai, J. Yan, and C.H. Zhang. 2015. Relationship between the bagging micro-environment and fruit quality in 'Guibao' peach (Prunus persica L. Batsch). J. Hort. Sci. Biotechnol. 90:303-310.

Zhang, X.J., L.X. Wang, Y.L. Liu, X.X. Chen, Y.Z. Yang, and Z.Y. Zhao. 2013. Differential gene expression analysis of 'Granny Smith' apple (Malus domestica Borkh.) during fruit skin coloration. S. Afr. J. Bot. 88:125-131.

Zhang, Y., P. Li, and L. Cheng. 2010. Developmental changes of carbohydrates, organic acids, amino acids, and phenolic compounds in 'Honeycrisp' apple flesh. Food Chem. 123:1013-1018.

Zhou, H., Z. Yu, and Z. Ye. 2019. Effect of bagging duration on peach fruit peel color and key protein changes based on iTRAQ quantitation. Scientia Hort. 246:217-226

Zhou, J., G. Zhong, Z. Lin, H.L. Xu, and F.M. Mathooko. 2012. The effects of bagging on fresh fruit quality of Canarium album. J. Food Agr. Environ. 10:505-508.

Zhu, Y.F., J. Su, G.F. Yao, H.N. Liu, C. Gu, M.F. Qin, B. Bai, S.S. Cai, G.M. Wang, R.Z. Wang, and Q. Shu. 2018. Different light-response patterns of coloration and related gene expression in red pears (Pyrus L.). Scientia Hort. 229:240-251. 